\title{
PENGENALAN BENTUK GEOMETRI MELALUI PENERAPAN MEDIA PASIR KINETIK UNTUK ANAK USIA 2-3 TAHUN DI PPT MAWAR O1AR-RACHMAN SURABAYA
}

\author{
Ilya Hidayati \\ PPT MAWAR 01 AR-RACHMAN, Surabaya \\ Ilyahidayatiarifin@gmail.com
}

\begin{abstract}
ABSTRAK
Salah satu permasalahan yang ditemui peneliti di PPT Mawar 01 adalah kurangnya pemahaman kognitif anak dalam mengenal bentuk geometri. Untuk mengatasi hal tersebut, peneliti berusaha memberikan pembelajaran melalui media pasir kinetik yang dapat menjadi salah satu alternatif menarik untuk media pembelajaran. Penelitian ini menggunakan metode Penelitian Tindakan Kelas (PTK). Hasil penelitian menunjukkan adanya peningkatan secara bertahap pada kemampuan mengenal bentuk geometri dengan bermain pasir kinetik. Peningkatan kemampuan mengenal bentuk geometri terlihat dari indikator kemampuan mengetahui, memahami, dan menerapkan bentuk geometri dalam bermain. Kemampuan anak dalam mengenal bentuk geometri melalui bermain pasir kinetik meningkat dari 27,7\% (tahap pra tindakan) menjadi sebesar 56\% (pada siklus I) dan meningkat menjadi 85\% (pada siklus II). Langkahlangkah yang dapat meningkatkan kemampuan mengenal bentuk geometri melalui media bermain pasir kinetik adalah melalui pengenalan bentuk lingkaran, segitiga, segiempat, persegi panjang, pengelompokan besar dan kecil, pengelompokan benda sesuai bentuknya, dan pengetahuan mengenai proses (sebab-akibat), serta antusias anak dalam melakukan kegiatan dari awal sampai akhir.
\end{abstract}

Kata Kunci: pasir kinetik, media pembelajaran, perkembangan kognitif

\begin{abstract}
One of the problems that encountered by researcher in the PPT Mawar 01 was the lack of the child's cognitive understanding to recognize geometric shapes. To overcome this problem, researcher tried to deliver learning through the kinetic sand medium that can be one of the interesting alternative to be a learning medium. This study used a Class Action Research (CAR) method. The results showed a gradual improvement in the ability to recognize geometric shapes by playing kinetic sand. The increased ability to know the geometric shapes can be seen on the indicator of the ability to know, understand, and apply of the geometric shapes in playing. Children's ability to recognize shapes through playing the geometric kinetic sand was increased from $27.7 \%$ (pre-action stage) to $56 \%$ (in the first cycle) and increased to $85 \%$ (the second cycle). The steps that can improving the ability to recognize geometric shapes through the playing medium of kinetic sand are through recognizing the shapes of circles, triangles, quadrangles, rectangles, grouping large and small, grouping objects according to their shape, knowing the process (the causes-effects), and the enthusiasm of children in carrying out activities from the beginning to the end.
\end{abstract}

Keywords: kinetic sand, learning medium, cognitive development. 


\section{PENDAHULUAN}

Geometri merupakan salah satu cabang ilmu matematika yang sangat terkait dengan bentuk, ukuran, dan pemposisian. Kemampuan dasar geometri dikembangkan melalui pengenalan anak terhadap kemampuan spasialnya, yaitu kemampuan yang berkaitan dengan bentuk benda dan tempat di mana benda tersebut berada, dan kemampuan berpikirnya adalah berpikir secara simbolis. Hal ini dapat dilihat dari kemampuan anak untuk dapat membayangkan benda-benda yang ada di sekitarnya. Pembelajaran melalui kegiatan bermain pasir kinetik untuk mengenal bentuk geometri dapat membantu anak untuk memahami, menggambarkan, dan mendeskripsikan benda-benda yang ada di sekitarnyaMenurut Dwi J (2010:266) Geometri adalah studi hubungan ruang. Pembelajaran anak usia dini termasuk pendalaman benda-benda serta hubungannya, sekaligus pengakuan bentuk dan pola. Anak mampu mengenali, mengelompokkan, dan menyebutkan namanama bentuk bangun, baik bangun datar ataupun bangun ruang yang bermacam-macam ukuran dan bentuknya. Pengenalan bentuk geometri dapat dikenalkan pada peserta didik melalui media bermain pasir kinetik, sehingga dapat berpengaruh pada tingkat perkembangan kognitif anak usia 2-3 tahun.

Perkembangan kognitif pada anak usia 2-3 tahun menurut Peraturan Menteri No. 137 tahun 2014 adalah anak mampu mengelompokan benda yang sejenis, mampu membedakan bentuk lingkaran, segitiga, segiempat, anak dapat memahami simbol dan maknanya serta anak mampu memahami konsep ukuran besar kecil. Perkembangan kognitif anak dapat distimulasi melalui bermain pasir kinetik. Karena dengan bermain pasir kinetik anak dapat bermain mencetak, menuang dan membuat berbagai macam bentuk geometri yang dikehendaki. Pendidik harus pandai memanfaatkan media pembelajaran yang ada, agar peserta didik dapat lebih mudah dalam menggali kemampuan kognitifnya. Salah satu media yang dapat meningkatkan perkembangan kognitif anak adalah media bermain pasir kinetik, konsep belajar dengan media bermain pasir kinetik sebagai permainan anak yang memberikan kebebasan berimajinasi.

Menurut undang-undang No. 20 tahun 2003 Media pembelajaran adalah sebuah alat yang berfungsi, untuk menyampaikan pesan dan informasi yang akan diberikan dalam suatu pembelajaran. (Depdiknas, 2003). Media pembelajaran untuk anak usia dini merupakan alat bantu yang digunakan pendidik untuk mengenalkan tema dan sub tema sebagai alat pembelajaran, untuk mempermudah peserta didik dalam menerima pembelajaran yang di sampaikan oleh pendidik. Semakin banyak alat indra yang terlibat dalam proses pembelajaran maka semakin besar pula kemungkinan anak paham pada materi yang disampaikan oleh pendidik. Pada saat ini, sebagaian besar media pembelajaran menggunakan media gambar dan ceramah. Padahal anak usia dini gampang jenuh dan bosan, dan lebih tertarik dengan hal baru. Untuk mengatasi kejenuhan dan kebosanan tersebut peneliti membuat alternatif untuk menggunakan media pasir kinetik dalam pembelajaran dengan tujuan untuk meningkatkan perkembangan kognitif anak usia 2-3 tahun.

Pasir Kinetik yang memiliki berbagai macam warna yang menarik menjadi salah satu media alternatif yang tepat dan dapat mengembangkan aspek perkembangan kognitif pada anak, untuk mengenalkan bentuk-bentuk geometri dan pengenalan warna sehingga 
anak dengan mudah mengerti tentang apa yang disampaikan oleh guru. Olivia $\mathrm{F}(2009: 68)$ mengungkapkan bahwa anak-anak dapat mempertahankan pesan sekitar $40 \%$ lebih baik jika ditampilkan dalam warna. Adapun kelebihan dari pasir kinetik yaitu, 1) pasir kinetik terjamin kebersihannya, sehingga aman digunakan untuk bermain. 2) tekstur pasir kinetik lembut, lebih halus dari pasir biasa, 3) sifatnya menempel dan lekat satu sama lain sehingga mudah untuk di bentuk sesuai yang di kehendaki.4) pasir kinetik memiliki berbagai macam warna yang menarik yang di sukai anak. 5) pasir kinetik dapat di gunakan sebagai media pembelajaran anak usia dini.

Merujuk pada beberapa paparan di atas, maka perlu adanya Stimulasi pada anak Usia 23tahun di PPT Mawar 1, Untuk meningkatkan perkembangan kognitifnya melalui bermain pasir kinetik, yang mana pada saat ini siswa-siswi PPT Mawar 1 dalam mengenal bentuk geometri perlu mendapatkan stimulasi yang optimal.Dalam menstimulasi aspek perkembangan kognitif anak usia dini harus disesuaikan dengan usia dan tahapan perkembanganya.Hal ini dikarena setiap anak walaupun memiliki usia yang sama tapi terkadang memiliki tahap perkembangan yang berbeda. Untuk merangsang semua aspek perkembangan anak usia dini tidak bisa lepas dari media pembelajaran, karena bagi anak usia dini belajar dilakukan melalui bermain dengan menggunakan media pembelajaran baik media nyata, media audio, media visual, media lingkungan sekitar maupun media audio visual, sehingga kegiatan pembelajaran pada anak usia dini berjalan secara efektif.

Adapun pembelajaran yang akan dikenalkan dalam bermain pasir kinetik adalah : 1) mengenal dan mengetahui bentuk geometri 2) membedakan bentuk geometri (segi tiga, lingkaran, persegi panjang, segi empat), 3) menyebutkan bentuk geometri (segi tiga, lingkaran, persegi panjang, segi empat),4) mengelompokan benda sesuai bentuknya.

\section{METODE}

Dalam penelitian ini menggunakan Metode penelitian tindakan kelas (PTK) (classroom action research) merupakan pendekatan penelitian yang peneliti gunakan didalam kasus penelitian kali ini. Menurut Hopkirs (RochiatiWiriaatmaja, 2005: 11) pengertian penelitian tindakan kelas adalah penelitian yang mengkombinasikan prosedur penelitian dengan tindakan subtansif, suatu tindakan yang dilakukan dalam disiplin inkuiri, atau usaha seseorang untuk memahami apa yang sedang terjadi sambil terlibat dalam sebuah peoses perbaikan dan perubahan.Penelitian ini dilaksanakan secara kolaboratif antara guru kelas dan teman sejawat dalam upaya meningkatkan perkembangan kognitif peserta didik melalui kegiatan bermain pasir kinetik untuk anak usia 2-3 tahun di PPT Mawar 01 Ar-Rachman Surabaya.Penelitian ini dirancang untuk memperoleh informasimengenai suatu keadaaan pada saat itu, diarahkan untuk menentukan sifat dari suatu situasi seperti yang ada waktu belajar anak. Ini bertujuan untuk menggambarkan 'apa yang ada' sehubungan dengan variabel atau kondisi dalam suatu situasi (Ary dan L.C.Razavieh, 1985 : 332)

Model Kemmis dan Mc Taggart dalam Arikunto (2006:97), alur penelitian itu terdiri dari empat kegiatan pokok, yaitu perencanaan (planning), pelaksanaan (acting), pengamatan (observing) dan refleksi (reflecting). Antara tindakan (acting) dan pengamatan (observing) sebagai satu kesatuan yang saling terkait. Hasil dari tindakan dan pengamatan dijadikan dasar untuk mencermati apa yang sudah terjadi (reflecting). Adapun 
proses pelaksanaan penelitian tindakan kelas ini sebagai berikut: 1) Perencanaan (planning),Kegiatan yang dilaksanakan pada tahap ini: a) Penyusunan rencana yang di awali dengan observasi mengenai kemampuan peserta didik dalam mengenal bentuk geomatri melalui media pasir kinetik. b) Merumuskan rencana tindakan yang akan dilakukan, dengan mempertimbangkan keadaan dan suasana objektif dan subjektif.2) Pelaksanaan(acting) dan pengamatan (observing),pada tahap pelaksanaan, guru melaksanakan kegiatan pembelajaran melalui media pasir kinetik untuk meningkatkan kognitif anak dalam mengenal konsep bentuk geometri dengan rencana yang dibuat saat tahap perencanaan. Pada tahap pengamatan, peneliti mengamati jalannya kegiatan pembelajaran di kelas yang sedang berlangsung. Untuk mendapatkan data yang diperlukan dalam penerapan pendekatan. 3) Refleksi (reflecting), data yang diperoleh dari pelaksanaan dan pengamatan dikumpulkan dan dianalisis sehingga diperoleh kesimpulan tentang berhasil atau tidaknya kegiatan pembelajaran yang dilaksanakan dengan penerapan pembelajaran melalui media pasir kinetik. Kekurangan, kelebihan, dan hasil yang diperoleh pada siklus 1 ini dijadikan acuan untuk melakukan perbaikan pada siklus II. Sebelum mengadakan penelitian lebih lanjut, peneliti mengadakan observasi yang disebut dengan pratindakan sebelum siklus I dan II. Pada Patindakan ini peneliti menggunakan media pembelajaran dengan menggunakan ampas berwarna untuk mengenalkan bentuk geometri pada anak, namun media ini hasilnya kurang optimal, karena ampas kering sulit untuk menyatu kalau dicetak atau gampang pudar, kebersihannya kurang terjamin dan tidak tahan lama dan mudah menjamur. Berangkat dari sini peneliti mencoba mencari media pembelajaran yang tepat yang dapat di gunakan untuk anak usia 2-3 tahun, yaitu dengan menggunakan media pasir kinetik.

Teknik pengumpulan data merupakan cara untuk mendapatkan data yang diperlukan dalam suatu penelitian dan akan mendukung suatu penelitian. Dalam penelitian ini, penelitian ini menggunakan teknik pengumpulan data sebagai berikut : 1) dokumentasi, merupakan teknik pengumpulan data yang diproses melalui dokumen-dokumen yang berupa foto-foto kegiatan siswa, hasil penilaian siswa untuk memperkuat data yang diperoleh selama peneletian. Dokumentasi yang digunakan dalam penelitian ini berfungsi sebagai data pelengkap penelitian. 2) Observasi, teknik pengumpulan data dengan observasi digunakan bila, penelitian berkenaan dengan perilaku manusia, proses kerja, gejala-gejala alam dan bila responden yang diamati tidak terlalu besar (Sugiyono,2009:203). Penelitian ini menggunakan teknik obsevasi partisipan (observasi langsung). Observasi dilakukan pada saat pembelajaran berlangsung, yang bertujuan untuk memperoleh data penggunaan media pasir kinetik dalam pembelajaran.

Pada penelitian ini peneliti menganalisa data yang telah di lakukan dalam siklus I dan Siklus II dengan menggunakan teknik diskritif kuantitatif prosentase. Adapun rumus Purwanto,Ngalim (2009) adalah sbb:

$$
\mathrm{P}=\frac{f}{N} \times 100 \%
$$

Keterangan :

$\mathrm{f}$ : Frekuensi yang sedang dicari presentasenya.

$\mathrm{N}$ : Jumlah Frekuensi

$\mathrm{P}$ : Angka presentase 


\section{PEMBAHASAN DAN HASIL PENELITIAN}

\section{Hasil Observasi Pratindakan}

Hasil observasi kemampuan kognitif dalam mengenal bentuk geometri pada pratindakan anak usia 2-3 tahun di PPT Mawar 01 Ar-Rachman yang dilakukan pada tanggal 09 Pebruari 2019 dan hasil pratindakan kepada anak usia 2-3 tahun di PPT Mawar 01 Ar-Rachman Surabaya dapat dilihat pada grafik dibawah ini :

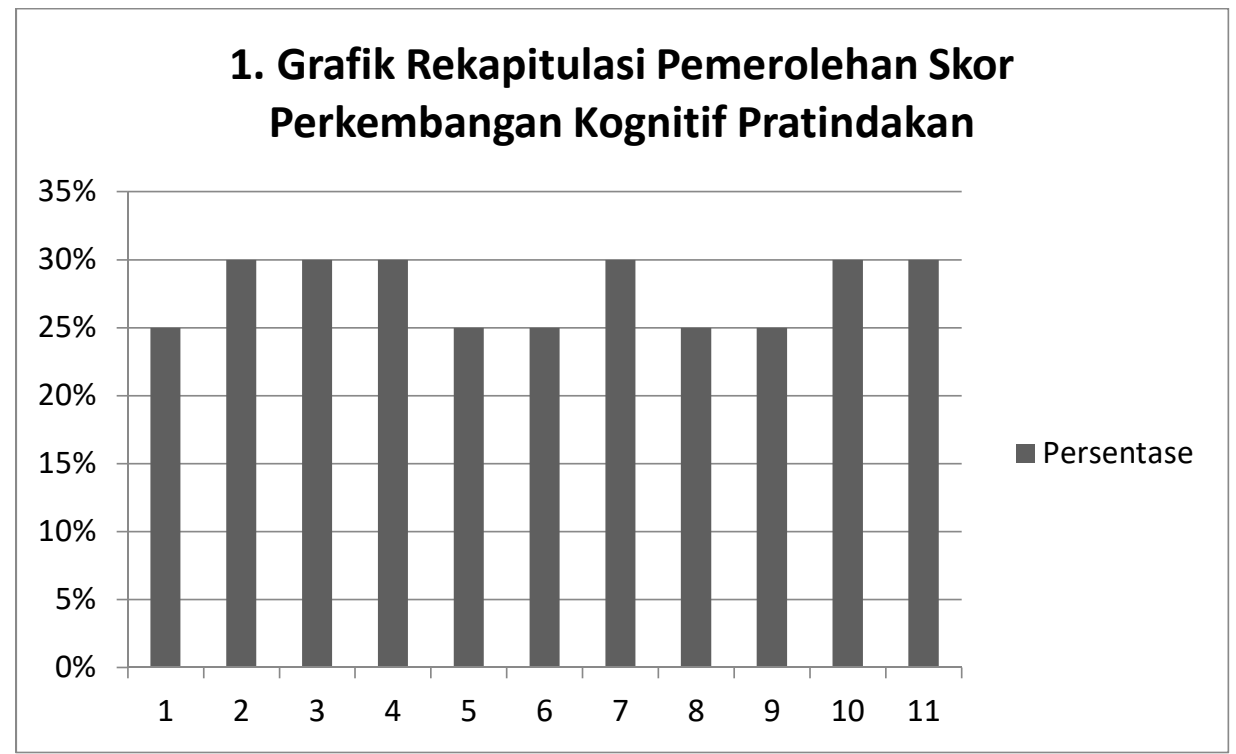

Berdasarkan data yang sudah diperoleh dari pratindakan dapat diketahui bahwa kemampuan kognitif anak pada materi mengenal bentuk- bentuk geometri di sekolah masih belum berkembang. Hal ini yang menjadi landasan peneliti untuk meningkatkan perkembangan kognitif anak pada materi mengenal bentuk-bentuk geometri anak usia 2-3 tahun di PPT Mawar 01 melalui media pembelajaran bermain ampas berwarna.

\section{Siklus I}

Pelaksanaan Siklus I dilaksanakan sebanyak tiga kali pertemuan yaitu pada hari Selasa tanggal 12 Pebruari 2019, Kamis tanggal 14 Pebruari 2019, dan Sabtu tanggal 16 Pebruari 2019, Setiap pertemuan anak akan dikenalkan bentuk geometri melalui cetakan yang sudah di sediakan sebelumnya oleh peneliti, mempersiapkan rancangan yang akan dilaksanakan pada kegiatan bermain pasir kinetik. Adapun hasil daripada siklus I dapat dilihat pada diagram dibawah ini : 


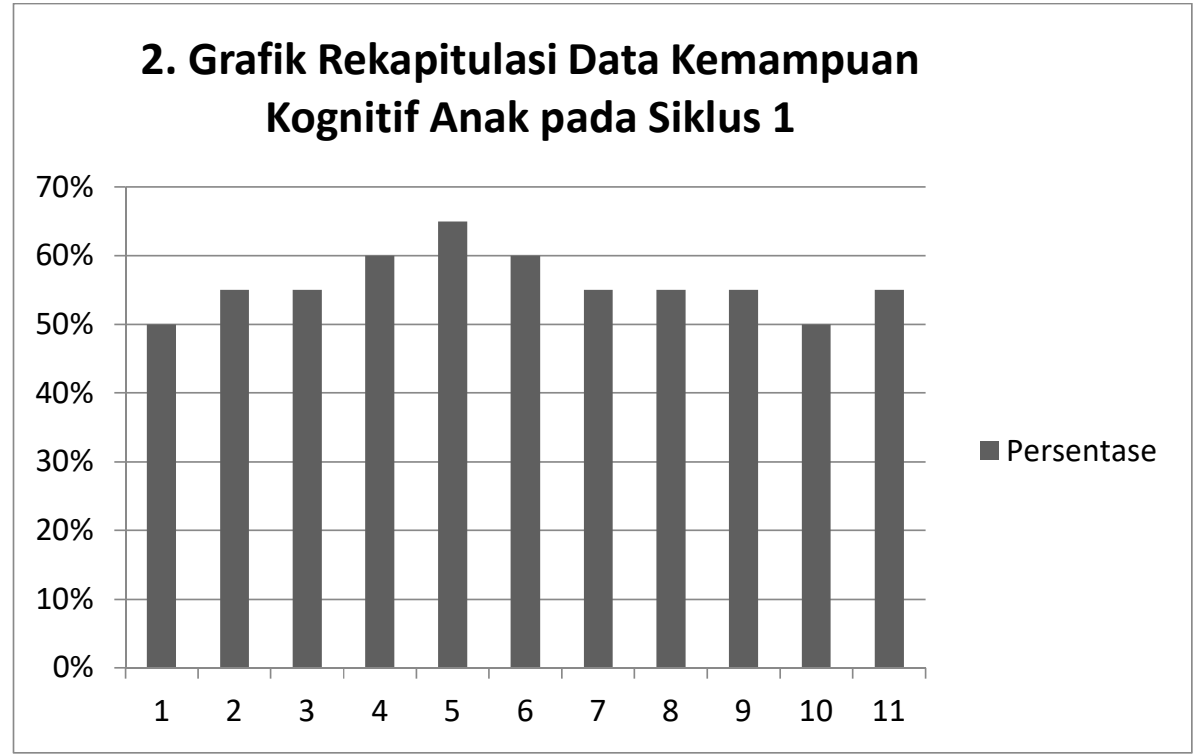

Berdasarkan grafik diatas yang dilakukan peneliti dengan guru pada akhir Siklus I, secara umum dari 11 anak, kemampuan kognitif anak pada materi mengenal bentuk bentuk geometri mulai berkembang. Hal ini berdasarkan hasil pengamatan peneliti pada Siklus I belum mencapai $75 \%$ dari jumlah anak, sehingga perlu dilaksanakan tindakan perbaikan pada Siklus II. Adapun permasalahan yang muncul selamaproses pembelajaran pada siklus I adalah : 1) Kurangnya pemahaman, sehingga anak masih bingung dengan materi geometri yang belum dikenalkan guru secara khusus., 2) Anak masih suka bercerita dan mengganggu teman saat proses kegiatan berlangsung. 3) Anak masih suka berebut cetakan yang diberikan guru sehingga ada yang bertengkar lalu tidak mau ikut kegiatan. 4) Kurangnya pemberian motivasi dan penguatan kepada anak saat proses pembelajaran berlangsung.

\section{Siklus II}

Pertemuan pertama Siklus II dilaksanakan pada hari Selasa tanggal 19 Pebruari 2019, kamis tgl 21 pebruari 2019, sabtu tgl 23 pebruari 2019. Tema yang diangkat Rekreasi dan sub tema Pergi ke lereng gunung. Seperti biasanya langkah-langkah sebelum pembelajaran berlangsung guru berinteraksi dulu dengan anak-anak. Menanyakan bagaimana kabarnya, kemudian di lanjutkan dengan bercerita tentang beberapa ciptaan Tuhan, salah satunya adalah gunung, kemudian di lanjutkan dengan bermain menangkap bola dilereng gunung. Kemudian dilanjutkan dengan bernyanyi dan do'a sebelum melakukan kegiatan inti.

Pada siklus II anak-anak mulai mengetahui aturan apa yang diberikan guru sebelum kegiatan pembelajaran di mulai. Anak mencetak bentuk geometri, kemudian mengelompkan sesuai jenisnya, dan mengelompokan besar dan kecil dari 
bentuk geometri. Anak mampu mengetahui sebab akibat dari hasil karya yang di buatnya sendiri,melalui cetakan. Dan antusias anak bisa mengikuti kegiatan dari awal sampai akhir. Adapun hasil Observasi dari pada Siklus ke II dapat dilihat dari grafik dibawah ini :

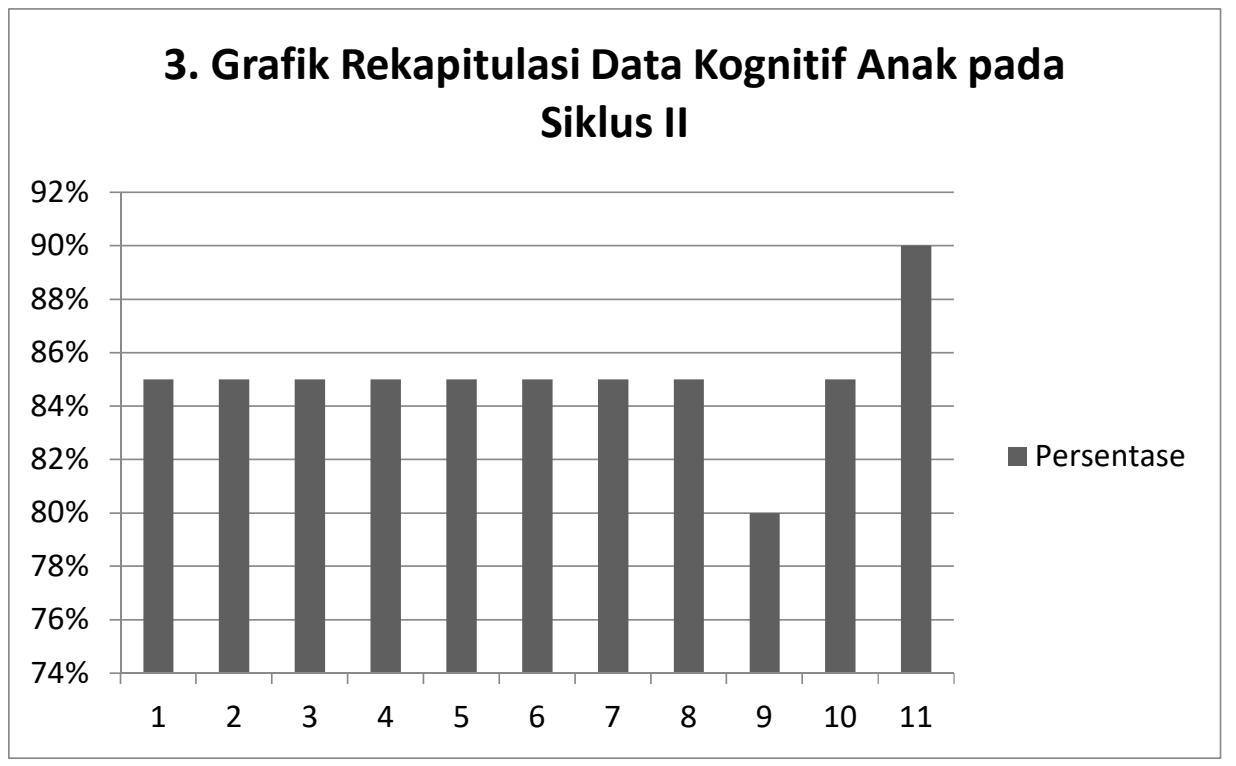

Berdasarkan tabel di atas dapat terlihat adanya peningkatan hasil pada setiap Siklusnya. Dan pencapaian indikator pada kemampuan Kognitif pada Siklus II mencapai $85 \%$ dari kelima instrument diatas. . Pada siklus II anakanak mulai mengetahui aturan apa yang diberikan guru sebelum kegiatan pembelajaran di mulai. Anak mencetak bentuk geometri, kemudian mengelompokkan sesuai jenisnya, dan mengelompokkan besar dan kecil dari bentuk geometri. Anak mampu mengetahui sebab akibat dari hasil karya yang dibuat, dari hasil cetakan yang dibuatnya sendiri, dan antusias anak bisa mengikuti kegiatan dari awal sampai akhir. Dengan demikian perkembangan kognitif anak sudah berkembang sangat baik dan rata-rata kelas sudah mencapai $85 \%$. Hasil tesebut telah mencapai batas kriteria yang akan dicapai peneliti sebesar 75\%. Berdasarkan hasil observasi siklus I dan siklus II yang telah dilaksanakan oleh peneliti, telah terjadi peningkatan perkembangan kognitif anak, maka dapat dperoleh grafik seperti dibawah ini : 


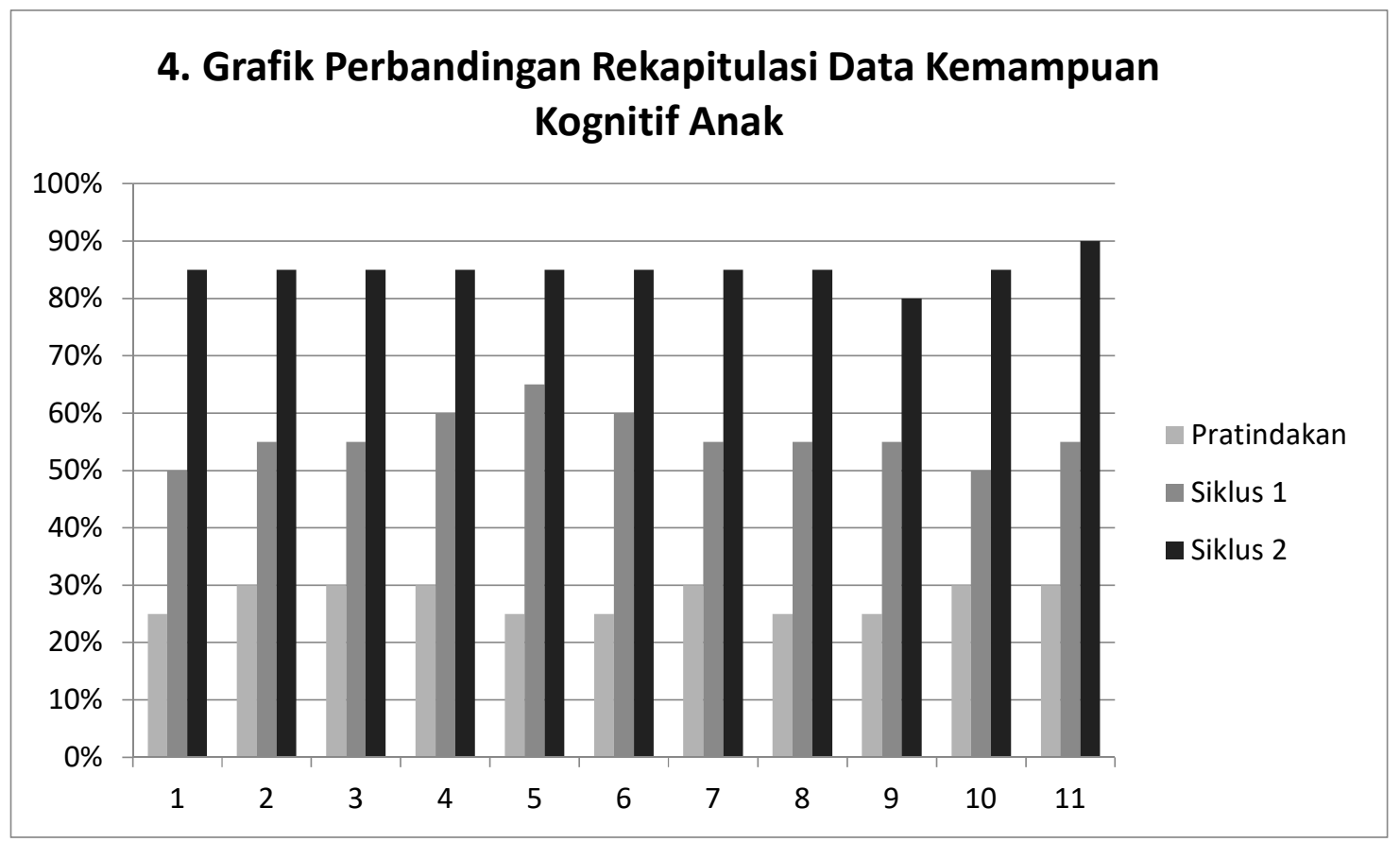

Berdasarkan data grafik diatasbahwa hasil penelitian "Pengenalan bentuk geometri melalui media pasir kinetik dapat meningkatkan perkembangan kognitif anak usia 2-3 tahun di PPT Mawar 01 Ar-Rachman Surabaya" dan meningkat secara bertahap. Hasil penelitian sebelum diberikan tindakan, sebesar 27,7\% Setelah dilakukan pemberian tindakan melalui pembelajaran dengan menerapkan model pembelajaran bermain pasir kinetik pada Siklus I, nilai rata-rata kelas meningkat 56\%. Pada Siklus II nilai rata-rata kelas semakin meningkat hingga mencapai $85 \%$.

Adapun untuk memenuhi tingkat keberhasilan anak, peneliti mengupayakan untuk memenuhi kekurangan-kekurangan yang ada pada Siklus I dan Siklus II misalnya, peneliti menstimulasi anak agar terangsang untuk melakukan kegiatan belajar dan bermain baik dengan lagu maupun permainan. Guru melakukan tindakan pada Siklus II yang tidak dilakukan pada Siklus I, misalnya memberikan cetakan kepada tiap-tiap anak agar anak tidak rebutan dan lebih kondusif saat tindakan dan pembelajaran di dalam kelas maupun di luar kelas berlangsung.

Gardner (dalam Triharso, 2013:7) menjelaskan bahwa pengenalan bentuk geometri yang baik, selain dapat meningkatkan perkembangan kognitifnya, anak dapat memahami lingkungannya. Selain itu anak mampu berpikir matematis logis dan dapat memahami konsep sederhana dalam kehidupan sehari-hari, seperti ketika anak melihat koin uang logam anak akan tahu kalau bentuknya lingkaran (bulat), buku bentuknya seperti segi empat, atap rumah bentuknya segitiga dan sebagainya. Dengan kemampuan berpikir matematis logis yang terasah dan terarah anak akan dapat berpikir secara logis dan rasional. Dalam Permendiknas 58 tahun 2009, disebutkan bahwa salah satu bidang pengembangan kognitif adalah mengenal konsep bentuk, dalam hal ini adalah bentuk geometri. Disini peneliti dapat menggunakan media bermain pasir kinetik. agar anak didik lebih antusias dalam bermain dan belajar. Selain itu pengenalan bentuk geometri 
apabila diterapkan dengan menggunakan media bermain pasir kinetik membuat peserta didik tetap mengingatnya, sehingga lebih mudah memahaminya dan perkembangan kognitif peserta didik meningkat. Media pasir kinetik bentuk geometri juga merupakan media yang dapat digunakan untuk kegiatan yang menyenangkan dan dapat menunjang tercapainya tujuan pembelajaran.

Hal ini sejalan dengan penelitian yang telah dilakukan oleh Vita Virgawati tahun 2015 (Virgawati vita, 2015) pada 30 anak di Paud Permata Bunda Kabupaten Sragen menggunakan media pasir berwarna bahwa terdapat pengaruh pada perkembangan kognitif anak. Adapun untuk memenuhi tingkat keberhasilan anak, peneliti mengupayakan untuk memenuhi kekurangan-kekurangan yang ada pada Siklus I dan Siklus II misalnya , peneliti menstimulasi anak agar terangsang untuk melakukan kegiatan belajar dan bermain baik dengan lagu maupun permainan. Guru melakukan tindakan pada Siklus II yang tidak dilakukan pada Siklus I, misalnya memberikan cetakan kepada tiap-tiap anak agar anak tidak rebutan dan lebih kondusif saat tindakan dan pembelajaran di dalam kelas maupun di luar kelas berlangsung.

Berdasarkan hasil di atas terbukti bahwa, dengan menerapkan media pembelajaran dengan media pasir kinetik dapat meningkatkan perkembangan Kognitif anak usia 2-3 tahun pada materi mengenal bentuk-bentuk geometri di PPT Mawar 01 Ar-Rachman Surabaya. Hal ini sejalan dengan pendapat yang di ungkapkan Sujiono dkk, (2005 : 29), Kemampuan perkembangan kognitif anak antara lain mengelompokan benda yang memiliki persamaan warna, bentuk dan ukuran, mencocokan lingkaran, segitiga, dan segi empat, serta mengenali dan menghitung angka 1 sampai 10. Dan diperkuat dengan Peraturan Menteri No. 137 tahun 2014 yang menyatakan bahwa perkembangan kognitif anak usia 2-3 tahun adalah anak mampu mengelompokan benda yang sejenis, anak mampu membedakan bentuk lingkaran, segitiga, segiempat, anak dapat memahami simbol dan maknanya serta anak mampu memahami konsep ukuran besar kecil.

\section{PENUTUP}

\section{Kesimpulan}

Berdasarkan hasil penelitian dan pembahasan, maka dapat disimpulkan bahwa :1) Dengan media bermain pasir kinetik, perkembangan kognitif anak pada materi mengenal bentukbentuk Geometri untuk anak usia 2-3 tahun di PPT Mawar 01 Ar-Rachman Surabaya dapat di tingkatkan. Medua pasir kinetik layak digunakan sebagai media dalam pembelajaran. 2) Penerapan media Pasir Kinetik dalam bentuk Geometri dapat meningkatkan perkembangan Kognitif anak usia 2-3 tahun di PPT Mawar 01 Ar-Rachman Surabaya. Dengan Presentase awal saat Pratindakan 27,7\%, setelah pelaksanaan pada Siklus I 56\% dan ketuntasan meningkat di Siklus II menjadi $85 \%$ dari indikator keberhasilan yang direncanakan. 


\section{DAFTAR PUSTAKA}

Ary, D. Jacobs, \& L.C.Razavieh. A. 1982. Pengantar Penelitian dalam Pendidikon. (Penerjemah Furchan,A). Surabaya: Usaha Nasional

Depdiknas. 2003. Undang-Undang No. 20 tahun 2003 Tentang Sistem Pendidikan Nasional.Jakarta

Olivia, Femi. 2009. Kembangkan Kecerdikan Anak Dengan Taktik Biosmart. Jakarta. PT Elex Media Komputindo.

Peraturan Menteri Pendidikan dan Kebudayaan Republik Indonesia Nomor 137 Tahun 2014 tentang Standar Nasional Pendidikan Anak Usia Dini.Jakarta

Purwanto,Ngalim. 2009. Evaluasi Hasil Belajar. Yogyakarta : Pustaka Pelajar

Sujiono,Bambang dan Yuliani Nurani Sujiono .2005. Menu Pembelajaran Anak Usia Dini. Jakarta: Yayasan Citra Pendidikan Indonesia.

Triharso, A. 2013. Permainan Kreatif dan Edukatif untuk Anak Usia Dini. Yogyakarta: Andi Yogyakarta.

Virgawati, Vita. 2015. Pengaruh Penggunaan Pasir Berwarna Sebagai Media Pembelajaran Terhadap Perkembangan Kognitif (Pengenalan Sains) Anak Usia 3-4 Tahun Di Paud Permata Bunda Kabupaten Sragen. Skripsi. Semarang. Universitas Negeri Malang 